\title{
Role of Antagonistic Microorganisms and Organic Amendment in Stimulating the Defense System of Okra Against Root Rotting Fungi
}

\author{
HAFIZA ASMA SHAFIQUE ${ }^{1}$, VIQAR SULTANA ${ }^{2}$, JEHAN ARA ${ }^{3}$, SYED EHTESHAMUL-HAQUE ${ }^{1}$ \\ and MOHAMMAD ATHAR ${ }^{3,4, *}$ \\ ${ }^{1}$ Agricultural Biotechnology and Phytopathology Laboratory, Department of Botany, \\ University of Karachi, Karachi, Pakistan \\ ${ }^{2}$ Biotechnology and Drug Development Laboratory, Department of Biochemistry, University of Karachi, \\ Karachi, Pakistan \\ ${ }^{3}$ Postharvest and Food Biochemistry Laboratory, Department of Food Science and Technology, \\ University of Karachi, Karachi, Pakistan \\ ${ }^{4}$ California Department of Food and Agriculture, Sacramento, CA, USA
}

Submitted 7 May 2014, accepted 27 February 2015

\begin{abstract}
Without application of chemical pesticides control of soilborne diseases is a great challenge. Stimulation of natural plant's defense is considered as one of the most promising alternative strategy for crop protection. Organic amendment of soil besides direct suppressing the pathogen, has been reported to have an influence on phytochemicals in plants. In the present study, Pseudomonas aeruginosa, a plant growth promoting rhizobacterium and Paecilomyces lilacinus, an egg parasite of root knot and cysts nematodes were examined individually and in combination in soil amended with cotton cake for suppressing the root rotting fungi and stimulating the synthesis of polyphenols and improving the antioxidant status in okra. Application of P. aeruginosa and P. lilacinus in soil amended with cotton cake significantly $(\mathrm{P}<0.05)$ suppressed Macrophomina phaseolina, Fusarium oxysporum, and Fusarium solani with complete reduction of Rhizoctonia solani. Combine use of biocontrol agents in cotton cake amended soil showed maximum positive impact on plant growth, polyphenol concentration and antioxidant activity in okra.
\end{abstract}

Ke y words: antagonistic microorganisms, okra, organic amendment, root rotting fungi

\section{Introduction}

Vegetable crops are vulnerable to a range of pathogenic organisms that reduce yield by killing the plant or damage the product and make it unmarketable. Plant diseases on average are responsible for up to $26 \%$ yield loss to global agriculture and sometimes there may be complete crop failure leading to $100 \%$ yield loss in a locality or a field (Khan et al., 2009). Okra [Abelmoschus esculentus (L.) Moench] is an important vegetable crop and is grown worldwide including Pakistan (Athar and Bokhari, 2006). Okra is a warm, rainy season crop and requires high temperature. However, diseases are the limiting factor in okra production. In Pakistan okra crop is attacked by various soil borne plant pathogenic fungi like Macrophomina phaseolina, Rhizoctonia solani, Fusarium spp. and the root knot nematodes Meloidogyne spp. (Afzal et al., 2013; Ehteshamul-Haque et al., 1996). Without application of chemical pesticides con- trol of soilborne diseases is a great challenge. Among the new biological approaches, the stimulation of natural plant's defense is considered as one of the most promising alternative strategies for crop protection (Anderson et al., 2006; Walters and Fountaine, 2009; Walters et al., 2005). This original biological approach does not exert direct effects on the pathogen (Walters and Fountaine, 2009) but stimulates natural defenses in plants, leading to a systemic acquired resistance (Vallad and Goodman, 2004).

Plants produce a wide range of secondary metabolites in response to biotic stress that are toxic to pathogens and herbivores. Phenolic phytochemicals are secondary metabolites that are common constituents of fruits and vegetables that function in the defense against insect and animal herbivory (Stevenson et al., 1993). These phenolic metabolites protect the plants against biological and environmental stresses and therefore are synthesized in response to pathogenic attack

\footnotetext{
* Corresponding author: M. Athar, California Department of Food and Agriculture, Sacramento, CA, USA; e-mail: atariq@cdfa.ca.gov
} 
such as fungal or bacterial infection or high energy radiation exposure such as prolonged UV exposure (Briskin, 2000). Phenolic phytochemicals, because of their important protective biological functions, are ubiquitous in all plants and therefore find their place in almost all food groups. In resistant plants, phenolic based defense responses are characterized by the early and rapid accumulation of phenolics at the infection site resulting in the effective isolation of the pathogen (Chérif et al., 1991).

Farmers and agricultural scientists have long understood that organic amendments applied to field soils improve soil functions such as infiltration, water holding capacity, nutrient retention and release, and resistance to wind and water erosion and can suppress soilborne diseases (Bonanomi et al., 2007; Stone et al., 2003). Beside a wide variety of organic matters that have been tested as organic amendments for managing plant pathogens, oil seed cakes can decrease the population of soil borne pathogens (Ehteshamul-Haque et al., 1995; Sharma et al., 1995). It has been observed that several antimicrobial by-products (e.g. organic acids, hydrogen sulfide, phenols, tannins and nitrogenous compounds) are released during the decomposition of organic amendments or synthesized by microorganisms involved in such degradation (Rodriguez-Kabana et al., 1995). Furthermore organic fertilizers enhance the antioxidant content in plants and consequently improve plant defense against pests and diseases (Dumas et al., 2003).

The root colonizing bacteria that have a beneficial effect on plants are termed as plant growth promoting rhizobacteria (PGPR) and have been reported to improve plant growth either through direct stimulation of the plant by producing growth regulators or by suppression of pathogens (Inam-ul-Haq et al., 2012; Weller et al., 2002). Of the various rhizospheric bacteria, the bacteria belonging to the fluorescent Pseudomonas which colonize roots of a wide range of crop plants are reported to be antagonistic to soil-borne plant pathogens (Siddiqui and Ehteshamul-Haque, 2001). PGPR may induce plant growth promotion by direct or indirect modes of action (Kloepper, 1993). Direct mechanisms include the production of stimulatory bacterial volatiles and phytohormones, lowering of the ethylene level in plant, improvement of the plant nutrient status (liberation of phosphates and micronutrients from insoluble sources; non-symbiotic nitrogen fixation) and stimulation of disease-resistance mechanisms (Antoun and Prévost, 2005). The present report describes the role of soil amendment and application of PGPR on the suppression of okra root diseases and polyphenol content and antioxidant activity in okra alone or with Paecilomyces lilacinus, an egg parasite of root knot and cyst nematodes.

\section{Experimental}

Materials and Methods

Biological antagonist. Cultures of P. aeruginosa and P. lilacinus, used in this study were obtained from Karachi University Culture Collection (KUCC).

Experimental design / Screen house experiment. Dry powder of cotton cake was mixed in sandy loam soil, pH 8.0, @ 1.0\% w/w. The soil had natural infestation of 5-11 sclerotia of M. phaseolina $\mathrm{g}^{-1}$ of soil, as determined by wet sieving and dilution technique (Shiekh and Ghaffar, 1975), 4-13\% colonization of sorghum seeds was used as bait for R. solani (Wilhelm, 1955), and $3000 \mathrm{cfu}^{-\mathrm{g}^{-1}}$ of soil of a mixed population of Fusarium solani and F.oxysporum as determined by a soil dilution technique (Nash and Synder, 1962). One $\mathrm{kg}$ of amended soil was transferred to $12 \mathrm{~cm}$ diameter clay pots. The pots were watered daily to allow the decomposition of the organic substrate. After two weeks, aqueous suspensions of $P$. aeruginosa $\left(10^{8} \mathrm{cfu} /\right.$ $\mathrm{ml})$ grown on $\mathrm{KB}$ broth and P. lilacinus $\left(10^{7} \mathrm{cfu} / \mathrm{ml}\right)$ grown on potato dextrose broth were drenched onto each pot at $25 \mathrm{ml}$ per pot. Pots without amendment/ antagonists or fungicides served as control. Aqueous suspension $(100 \mathrm{ppm})$ of a fungicide, carbondazim at $25 \mathrm{ml}$ per pot served as positive control. Six seeds of okra were sown in each pot and pots were kept randomized on a screen house bench of Department of Botany at 50\% water holding capacity with four replicates of each treatment. After germination, only four seedlings were kept and excess were removed.

Determination of fungal infection and growth parameter. To assess the efficacy of P. aeruginosa and P. lilacinus in suppression of root disease, plants were uprooted after 45 days of growth. To determine the incidence of fungi, roots were washed with running tap water then surface disinfested with $1 \% \mathrm{Ca}(\mathrm{OCl})_{2}$ and $1 \mathrm{~cm}$ long root pieces from tap roots, (5 from each plant) were plated onto potato dextrose agar plates supplemented with penicillin (100,000 units/litre) and streptomycin $(0.2 \mathrm{~g} / \mathrm{litre})$. After incubation for 5 days at $28^{\circ} \mathrm{C}$, the incidence of root infecting fungi was recorded. Infection percentage for each pathogen was calculated using the formula:

$\begin{aligned} & \text { Infection } \% \\ & \text { of a pathogen }\end{aligned}=\frac{\text { Number of plants infected by a pathogen }}{\text { Total number of plants }} \times 100$

Plant growth parameters, such as plant height and fresh weight of shoot, root length and root weight were also recorded.

Determination of polyphenol. Okra leaves were oven-dried at $80^{\circ} \mathrm{C}$ for 24 hours. Dried leaves were ground into fine powder using a clean pestle mortar and finally crushed samples were suspended in etha- 
nol. Samples were collected in screw capped centrifuge tubes. The extracts were centrifuged for 20 minutes at $3,000 \mathrm{rpm}$. The supernatants were collected and used for analyzing phenolic content and antioxidant activity.

The estimation of polyphenol was done by FolinCiocalteu phenol reagent as describe by Chandini et al., (2008). For estimation $100 \mu \mathrm{l}$ aliquots of ethanolic leaves extract were mixed with $2 \mathrm{ml}$ of $2 \% \mathrm{Na}_{2} \mathrm{CO}_{3}$ and allowed to stand for 2 minutes at room temperature. After incubation $100 \mu \mathrm{l}$ Folin-Ciocalteu phenol reagent was added and mixture was mixed thoroughly and allowed to stand for 30 minutes at room temperature in dark. Absorbance of samples was recorded at $720 \mathrm{~nm}$ using spectrophotometer and phenolic content was expressed as gallic acid equivalents.

DPPH radical scavenging activity. Antioxidant activity in okra was determined using DPPH (2, 2-Diphenyl-1-picrylhydrazyl) assay (Zubia et al., 2007) with some modification. An aliquot of $200 \mu \mathrm{l}$ of ethanolic leaves extract $(0.2 \mathrm{mg} / \mathrm{ml}$ of ethanol) was mixed with $800 \mu \mathrm{l}$ of $100 \mathrm{mM}$ Tris-HCl buffer (PH 7.4). The mixture was added to $30 \mu \mathrm{M} \mathrm{DPPH} \mathrm{(dissolved} \mathrm{in} \mathrm{DMSO)}$ and vortex, then left to stand at room temperature in the dark. The absorbance was measured at $517 \mathrm{~nm}$ after 1 minute and 30 minute of incubation, using UV-visible spectrophotometer against ethanol, used as blank. One $\mathrm{ml}$ ethanol with $1 \mathrm{ml}$ of DPPH was used as control. Synthetic BHT was used as positive control. The ability to scavenge the DPPH radical was calculated using the follow equation:

$$
\% \text { of inhibition }=\frac{A_{\text {control }}-A_{\text {sample }}}{A_{\text {control }}} \times 100
$$

Where the $\mathrm{A}_{\text {control }}$ is the absorbance of the control (DPPH solution without sample), the $A_{\text {sample }}$ is the absorbance of the test sample (DPPH solution plus test sample).
Statistical analysis. The experiment was conducted twice and data were subjected to analysis of variance (ANOVA) and means were separated using the least significant difference (LSD) according to (Gomez and Gomez, 1984).

\section{Results}

Influence of cotton cake and antagonistic microorganism on plant growth and development of root rot infection. Application of cotton cake 1\% alone or with PGPR and P. lilacinus showed positive impact on plant growth by improving plant height, fresh shoot weight and root length. PGPR and P. lilacinus with cotton cake $1 \% \mathrm{w} / \mathrm{w}$ significantly $(\mathrm{P}<0.05)$ increased plant growth and caused maximum reduction in diseases severity. Greater plant height was observed in mixed treatment of cotton cake with PGPR and P. lilacinus followed by $P$. lilacinus together with cotton cake. A significant increase in fresh shoot weight was found where cotton cake $1 \% \mathrm{w} / \mathrm{w}$ was used followed by cotton cake with carbendazim or cotton cake with P. lilacinus (Table I). Highest root length was observed by the application of carbendazim used in amended soil, whereas greater fresh root weight was recorded in cotton cake with P. lilacinus treatment (Table I). Application of PGPR and P. lilacinus in soil amended with cotton cake $1 \%$ significantly suppressed infection of M. phaseolina, Fusarium oxysporum, F. solani with complete inhibition of $R$. solani (Table II). Use of carbendazim with cotton cake also significantly inhibited root rotting fungi as compare to the control. Soil application of cotton cake alone also showed reduction of M. phaseolina, R. solani, and F. solani. P. lilacinus in cotton cake amended soil also showed suppressive effect on root rotting fungi (Table II).

Table I

Effect of $P$. aeruginosa and P. lilacinus on growth of okra plants in soil amended with cotton cake $(1 \% \mathrm{w} / \mathrm{w})$

\begin{tabular}{|l|c|c|c|c|}
\hline \multicolumn{1}{|c|}{ Treatments } & $\begin{array}{c}\text { Shoot length } \\
(\mathrm{cm})\end{array}$ & $\begin{array}{c}\text { Fresh shoot weight } \\
(\mathrm{g})\end{array}$ & $\begin{array}{c}\text { Root length } \\
(\mathrm{cm})\end{array}$ & $\begin{array}{c}\text { Root weight } \\
(\mathrm{g})\end{array}$ \\
\hline Control & 27.84 & 4.05 & 9.4 & 0.60 \\
\hline Carbendazim & 28.08 & 3.65 & 11.58 & 0.31 \\
\hline Cotton cake $(1 \% \mathrm{w} / \mathrm{w})$ & 26.68 & 6.51 & 7.98 & 0.49 \\
\hline P. aeruginosa & 29.09 & 3.01 & 9.51 & 0.25 \\
\hline P. lilacinus & 30.62 & 2.82 & 6.75 & 0.17 \\
\hline P. aeruginos + P. lilacinus & 28.56 & 2.77 & 8.65 & 0.26 \\
\hline Cotton cake + carbendazim & 28.05 & 6.40 & 11.16 & 0.54 \\
\hline Cotton cake + P. aeruginosa & 28.28 & 5.30 & 7.19 & 0.44 \\
\hline Cotton cake + P. lilacinus & 32.12 & 6.79 & 7.78 & 1.63 \\
\hline Cotton cake + P. aeruginosa + P. lilacinus & 33.01 & 5.59 & 9.64 & 0.64 \\
\hline LSD $_{0.05}$ & $5.78^{1}$ & $1.54^{1}$ & $2.91^{1}$ & $\mathrm{~ns}$ \\
\hline
\end{tabular}

${ }^{1}$ Mean values in column showing differences greater than LSD values are significantly different at $\mathrm{p}<0.05$ 
Table II

Effect of P. aeruginosa and P. lilacinus on the infection of M. phaseolina, R. solani, F. solani and F. oxysporum in soil amended with cotton cake $(1 \% \mathrm{w} / \mathrm{w})$

\begin{tabular}{|c|c|c|c|c|}
\hline Treatments & F. oxysporum & F. solani & M.phaseolina & R. solani \\
\hline \multicolumn{5}{|c|}{ Infection \% } \\
\hline Control & 43.7 & 18.7 & 62.5 & 31.2 \\
\hline Carbendazim & 37.5 & 6.2 & 43.7 & 62.5 \\
\hline Cotton cake $(1 \% \mathrm{w} / \mathrm{w})$ & 50 & 12.5 & 25 & 18.7 \\
\hline P. aeruginosa & 50 & 6.2 & 43.7 & 43.7 \\
\hline P. lilacinus & 43.7 & 25 & 43.7 & 37.5 \\
\hline P. aeruginosa + P. lilacinus & 50 & 18.7 & 25 & 25 \\
\hline Cotton cake+ carbendazim & 25 & 18.7 & 43.7 & 25 \\
\hline Cotton cake $+P$. aeruginosa & 18.7 & 18.7 & 37.5 & 18.7 \\
\hline Cotton cake + P. lilacinus & 12.5 & 18.7 & 12.5 & 6.2 \\
\hline Cotton cake $+P$. aeruginosa $+P$. lilacinus & 6.2 & 12.5 & 18.7 & 0 \\
\hline
\end{tabular}

$\mathrm{LSD}_{0.05}=$ Treatments $=18.09^{1}$, Pathogens $=11.44^{2}$

${ }^{1}$ Mean values in column showing differences greater than LSD values are significantly different at $\mathrm{p}<0.05$

${ }^{2}$ Mean values in rows showing differences greater than LSD values are significantly different at $\mathrm{p}<0.05$

Table III

Effect of P. aeruginosa and P. lilacinus on antioxidant activity and polyphenol contents in okra in soil amended with cotton cake $(1 \% \mathrm{w} / \mathrm{w})$

\begin{tabular}{|l|c|c|c|}
\hline \multirow{2}{*}{ Treatments } & \multicolumn{2}{|c|}{ Antioxidant activity (\% inhibition) } & Phenolic contents \\
\cline { 2 - 3 } & 1 minute & 30 minutes & (mg\% gallic acid) \\
\hline Standard (BHT) & $80.32^{\mathrm{a}}$ & $62.66^{\mathrm{a}}$ & --- \\
\hline Control & $20.92^{\mathrm{e}}$ & $31.5^{\mathrm{de}}$ & $37.25^{\mathrm{b}}$ \\
\hline Carbendazim & $29.75^{\mathrm{cde}}$ & $31.05^{\mathrm{de}}$ & $34.25^{\mathrm{b}}$ \\
\hline Cotton cake (1\% w/w) & $49.95^{\mathrm{b}}$ & $52.30^{\mathrm{abc}}$ & $45.25^{\mathrm{ab}}$ \\
\hline P. aeruginosa & $24.72^{\mathrm{de}}$ & $33.58^{\mathrm{de}}$ & $50.0^{\mathrm{ab}}$ \\
\hline P. lilacinus & $8.25^{\mathrm{f}}$ & $25.33^{\mathrm{e}}$ & $39.15^{\mathrm{b}}$ \\
\hline P. aeruginos + P. lilacinus & $25.13^{\mathrm{de}}$ & $36.94^{\mathrm{cde}}$ & $42.5^{\mathrm{ab}}$ \\
\hline Cotton cake + carbendazim & $39.82^{\mathrm{bc}}$ & $53.88^{\mathrm{abc}}$ & $35.5^{\mathrm{b}}$ \\
\hline Cotton cake + P. aeruginosa & $38.62^{\mathrm{bcd}}$ & $46.2^{\mathrm{abcd}}$ & $45.75^{\mathrm{ab}}$ \\
\hline Cotton cake + P. lilacinus & $33.20^{\text {cde }}$ & $42.99^{\mathrm{bcde}}$ & $48.25^{\mathrm{ab}}$ \\
\hline Cotton cake + P. aeruginosa + P. lilacinus & $33.19^{\text {cde }}$ & $57.66^{\mathrm{ab}}$ & $57.75^{\mathrm{a}}$ \\
\hline LSD & $12.64^{\mathrm{a}}$ & $16.13^{1}$ & $14.09^{1}$ \\
\hline
\end{tabular}

Mean values in column bearing same superscript letters are not significantly $(\mathrm{P}<0.05)$ different according to Duncan's multiple range test

${ }^{1}$ Mean values in column showing differences greater than LSD values are significantly different at $(\mathrm{P}<0.05)$

Polyphenols content. In this study, phenolic content was measured in terms of $\mathrm{mg} \%$ gallic acid equivalent (mg\% GAE) using the Folin Ciocalteu reagent (Table III). Cotton cake $1 \%$ alone or with PGPR and P.lilacinus showed phenolic content ranged from ( $45.25 \mathrm{mg} \%$ GAE to $57.75 \mathrm{mg} \%$ GAE). Combined soil application with cotton cake + PGPR + P. lilacinus showed significantly $(\mathrm{P}<0.05)$ higher polyphenols $(57.75 \mathrm{mg} \% \mathrm{GAE})$ as compared to the control and chemical fungicide, carbendazim treatments i.e., $37.25 \mathrm{mg} \%$ and $34.25 \mathrm{mg} \%$ GAE respectively. Appli- cation of PGPR alone also showed higher phenolic content (50 $\mathrm{mg} \% \mathrm{GAE}$ ) as compared to the P. lilacinus (39.15 mg\% GAE) used alone but with cotton cake showed (48.25 mg\% GAE).

DPPH radical scavenging activity. DPPH Radical Scavenging Assay-1, 1-diphenyl-2-picryl hydrazyl (DPPH) was used in this study to determine the freeradical scavenging activity of the plant samples. This is a stable free radical whose color changes from violet to yellow when it is reduced by hydrogen donation. Butylated hydroxytoluene (BHT) was used as a stand- 
ard. The activity of leaves extract at two different time intervals i.e. at 1 minute and 30 minute were observed. The activity of extracts increased with the time of incubation as compare to BHT as shown in (Table III). The antioxidant activity initially was weaker than standard but increased with time. The activity was significantly $(\mathrm{P}<0.05)$ higher $(57.66 \%)$ in $\mathrm{PGPR}+P$. lilacinus treated plants in amended soil. Okra plants with chemical fungicide and without any treatment showed lowest antioxidant activity $(31.5 \%, 31.05 \%)$. It was also observed that extracts which show highest polyphenols, showed highest antioxidant activity (Table III). Furthermore antioxidant activity was reached more than $50 \%$ in plants grown in cotton cake amended soil alone or with carbendazim or with PGPR + P. lilacinus (Table III).

\section{Discussion}

The biological control of soil-borne pathogens with mixture of biocontrol agents, organic amendments and micronutrients is a new approach in crop protection to reduce the disease damage level in economically important crops (Bharathi et al., 2004). In this study soil amendment with cotton cake caused significant control of root rotting fungi and improved growth of okra. Organic amendments are generally used for improving crops, increasing agricultural productivity and suppressing soil borne diseases (Stone et al., 2003; Sultana et al., 2011). Among the wide variety of organic matters tested as organic amendments for managing plant pathogens oil seed cakes significantly suppressed the soilborne pathogens (Ehteshamul-Haque et al., 1995; Sharma et al., 1995).

In this study application of PGPR or P. lilacinus in amended soil showed promising results by reducing the soilborne pathogens, producing the healthier plants and improving the antioxidant status of the okra plants. There are reports that microbiota, e.g. rhizobacteria, Trichoderma, and Pseudomonas spp., present in decomposing organic matter may enhance growth and yield of crops (Sylvia, 2004) by producing plant growth hormones and chemical compounds (e.g. siderophores, tannins, phenols) which are antagonistic to various soilborne pathogens (Antonio etal., 2008). In this study plants grown in cotton cake amended soil and received both PGPR and P. lilacinus showed maximum amount of polyphenols as compared to other treatments. Organic fertilization has been reported to have larger impact on the phyto-nutritional quality of crops. Phenolic compounds are important plant secondary metabolites that can help plants tide over oxidative stress working as antioxidants (Grassmann etal., 2000; Urquiaga and Leighton, 2000). Toor et al. (2006) reported that organic fertilizers increased the content of ascorbic acid and total phenolics in tomato. Similarly Dumas et al. (2003) reported that inorganic fertilizers reduce the antioxidants while organic fertilizers were proved to enhance the antioxidant content in plants. It is also known that phenolic compounds are potential antioxidants and free radical- scavengers. Kumar et al. (2008) reported that there should be a close relation between the content of phenolic compounds and antioxidant activity.

Fertilizer and pesticide affect the human health and cause damage to the environment. Application of organic amendment and biocontrol agents are environmental friendly and an alternative strategy to the prevalent use of synthetic pesticides. Combination of introduced biocontrol agents with oil cake was more consistent against disease suppression. The results of the present study show that mixed application of oil cake with PGPR and P. lilacinus enhance plant growth and suppress the infection of soil borne root rotting fungi via increasing the polyphenols and antioxidant activity in okra plants.

\section{Literature}

Afzal S, S. Tariq, V. Sultana, J. Ara and S. Ehteshamul-Haque. 2013. Managing the root diseases of okra with endo-root plant growth promoting Pseudomonas and Trichoderma viride associated with healthy okra roots. Pak. J. Bot. 45: 1455-1460.

Anderson A.J., K.A. Blee and K.Y.Yang. 2006. Commercialization of plant systemic defense activation: theory, problems and successes, pp. 386-414. In: Tuzun T. and E. Bent (eds). Multigenic and Induced Systemic Resistance in Plants. Springer, New York, USA.

Antonio G.F., C.R. Carlos, R.R. Reiner, A.A. Miguel, O.L.M. Angela, M.J.G. Cruz and L. Dendooven. 2008. Formulation of a liquid fertiliser for sorghum (Sorghum bicolour (L.) Moench) using vermicompost leachate. Bioresour. Technol. 99: 6174-6180.

Antoun H. and D. Prévost. 2005. Ecology of plant growth promoting rhizobacteria, pp. 1-38. In: Siddiqui Z.A. (ed.). PGPR: Biocontrol and Biofertilization, Springer, Netherlands.

Athar M. and T.Z. Bokhari. 2006. Ethnobotany and production constraints of traditional and commonly used vegetables of Pakistan. J. Vegetable. Sci. 12: 27-38.

Bharathi R., R. Vivekananthan, S. Harish, A. Ramanathan and R. Samiyappan, R. 2004. Rhizobacteria-based bio-formulations for the management of fruit rot infection in chillies. Crop Prot. 23: 835-843. Bonanomi G., V. Antignani, C. Pane and F. Scala. 2007. Suppression of soilborne fungal pathogens with organic amendments. J. Pl. Pathol. 89: 311-324.

Briskin D.P. 2000. Medicinal plants and phytomedicines. Linking plant biochemistry and physiology to human health. Plant Physiol. 124: 507-514.

Chandini, S.K., P. Ganesan and N. Bhaskar. 2008. In vitro antioxidant activities of three selected brown seaweeds of India. Food Chem. 107: 707-713.

Chérif M., N. Benhamou and R.R. Bélangeret. 1991. Ultrastructural and cytochemical studies of fungal development and host reactions in cucumber plants infected by Pythium ultimum. Physiol. Mol. Pl. Pathol. 39: 353-375.

Dumas Y., M. Dadomo, G. Di Lucca and P. Grolier. 2003. Effects of environmental factors and agricultural techniques on antioxidant content of tomatoes. J. Sci. Food Agric. 83: 369-382. 
Ehteshamul-Haque S., M. Abid and A. Ghaffar. 1995. Efficacy of Bradyrhizobium sp., Paecilomyces lilacinus with oilcakes in the control of root rot of mungbean. Trop. Sci. 35: 294-299.

Ehteshamul-Haque S., M. Abid, V. Sultana, J. Ara and A. Ghaffar. 1996. Use of organic amendments on the efficacy of biocontrol agents in the control of root rot and root knot disease complex of okra. Nematol. Medit. 24: 13-16.

Gomez K.A. and A.A. Gomez. 1984. Statistical Procedures for Agricultural Research. $2^{\text {nd }}$ ed. Wiley, New York.

Grassmann J., S. Hippeli and E.F. Elstner. 2000. Plant's defense and its benefits for animals and medicine: role of phenolics and terpenoids in avoiding oxygen stress. Pl. Physiol. Biochem. 40: 471-478. Inam-ul-Haq M., S. Mehmood, H.M. Rehman, Z. Ali and M.I. Tahir. 2012. Incidence of root rot diseases of soybean in Multan, Pakistan and its management by the use of plant growth promoting rhizobacteria. Pak. J. Bot. 44: 2077-2080.

Khan M.R., S. Altaf, F.A. Mohiddin, U. Khan and A. Anwer. 2009. Biological control of plant nematodes with phosphate solubilizing microorganisms, pp. 395-426. In: Khan M.S. and A. Zaidi (eds). Phosphate Solubilizing Microbes for Crop Improvement. Nova Science Publishers Inc., New York, USA.

Kloepper J.W. 1993. Plant-growth-promoting rhizobacteria as biological control agents, pp. 255-273. In: Metting Jr. F.B. (ed.). Soil Microbial Ecology. Marcel Dekker Inc., New York, USA.

Kumar K.S., K. Ganesan and P.V. Subba Rao. 2008. Antioxidant potential of solvent extracts of Kappaphycus alvarezii Doty-An edible seaweed. Food Chem. 107: 289-295.

Nash S.M. and W.C. Snyder. 1962. Quantitative estimations by plate counts of propagules of the bean root rot Fusarium in field soils. Phytopath. 52: 567-572.

Rodriguez-Kabana R., V. Estaun, J. Pino-Chet and O. Marfa. 1995. Mixtures of olive pomace with different nitrogen sources for the control of Meloidogyne spp. on tomato, Suppl. J. Nematol. 27: 575-584.

Sharma S.K., R.K. Aggarwal and S. Lodha. 1995. Population changes of Macrophomina phaseolina and Fusarium oxysporum $\mathrm{f}$. sp. cumini in oilcake and crop residue amended sandy soils. Appl. Soil Ecol. 2: 281-284.

Sheikh A.H. and A. Ghaffar. 1975. Population study of sclerotia of Macrophomina phaseolina in cotton fields. Pak. J. Bot. 7: 13-17.
Siddiqui I.A. and S. Ehteshamul-Haque. 2001. Suppression of the root rot-root knot disease complex by Pseudomonas aeruginosa in tomato: The influence of inoculum density, nematode population, moisture and other plant associated bacteria. Plant Soil 237: 81-89. Stevenson P.C., J.C. Anderson, W.M. Blaney and M.S.J. Simmonds. 1993. Developmental inhibition of Spodoptera litura (Fab.) larvae by a novel caffeoylquinic acid from the wild groundnut, Arachis paraguariensis. J. Chem. Ecol. 19: 2917-2933.

Stone A.G., G.E. Vallad, L.R. Cooperband, D. Rotenberg, H.M. Darby, R.V. James, W.R. Stevenson and R.M. Goodman. 2003. Effect of organic amendments on soilborne and foliar diseases in field-grown snap bean and cucumber. Plant Dis. 87: 1037-1042. Sultana V., G.N. Baloch, J. Ara, S. Ehteshamul-Haque, R.M. Tariq and M. Athar. 2011. Seaweeds as alternative to chemical pesticides for the management of root diseases of sunflower and tomato. J. Appl. Bot. Food Qual. 84: 162-168.

Sylvia E.W. 2004. The effect of compost extract on the yield of strawberries and severity of Botrytis cinerea. J. Sustain. Agric. 25.

Toor R.K., G.P. Savage and A. Heeb. 2006. Influence of different types of fertilizers on the major antioxidant components of tomatoes. J. Food Compos. Anal. 19: 20-27.

Urquiaga I. and F. Leighton. 2000. Plant polyphenol antioxidants and oxidative stress. Biol. Resour. 33: 55-64.

Vallad G.E. and R.M. Goodman. 2004. Systemic acquired resistance and induced systemic resistance in conventional agriculture. Crop Sci. 44: 1920-1934.

Walters D., D. Walsh, A. Newton and G. Lyon. 2005. Induced resistance for plant disease control: maximizing the efficacy of resistance elicitors. Phytopath. 95: 1368-1373.

Walters D.R. and J.M. Fountaine. 2009. Practical application of induced resistance to plant diseases: an appraisal of effectiveness under field conditions. J. Agric. Sci. 147: 523-535.

Weller D.M., J.M. Raaijimakers, B.B.M. Gardener and L.S. Thomashow. 2002. Microbial population responsible for specific soil suppressiveness to plant pathogens. Annu. Rev. Phytopathol. 40: 309-348. Wilhelm S. 1955. Longevity of the Verticillium wilt fungus in the laboratory and field. Phytopath. 45: 180-181.

Zubia M., D. Robledo and Y. Freile-Pelegrin. 2007. Antioxidant activities in tropical marine macro-algae from the Yucatan Peninsula, Mexico. J. Appl. Phycol. 19: 449-458. 